\begin{abstract}
Alma Vančura
avancura@ffos.hr

Filozofski fakultet Sveučilišta Josipa Jurja Strossmayera u Osijeku

Hrvatska
\end{abstract}

\title{
3. Međunarodna konferencija o retorici "Dani Ive Škarića". Postira, Hrvatska, od 20. do 23. travnja 2016. godine
}

Međunarodna konferencija o retorici "Dani Ive Škarića" održana je treći put u Postirama na Braču, rodnom mjestu uvaženog promicatelja retorike i javnoga govorenja, professora emeritusa Ive Škarića. Hrvatski i međunarodni stručnjaci za retoriku, stilistiku, teoriju argumentacije i druge srodne discipline, okupili su se kako bi predstavili, raspravili i razmijenili različite spoznaje o retorici i teoriji argumentacije. Glavne su teme konferencije bile: argumentacijska teorija, retorika političkog diskursa, argumentacija i pravo, retorika i jezik, vizualna i multimodalna retorika, retorika i stilistika, retorika religijskog diskursa te retorika i obrazovanje. Svoja istraživanja predstavila su 42 znanstvenika u 37 izlaganja, a budući da je većina izlagača već sudjelovala na prethodnim konferencijama "Dani Ive Škarića", rasprave nakon izlaganja prošle su u ugodnom, opuštenom te konstruktivnom tonu. Osim hrvatskih izlagača, sudionike konferencije činili su i znanstvenici iz Kanade, Sjedinjenih Američkih Država, Francuske, Italije, Mađarske, Nizozemske, Njemačke, Poljske, Slovenije, Švedske, Ujedinjenog Kraljevstva i Ukrajine. Početak svakog dana konferencije bio je rezerviran za plenarna predavanja pozvanih predavača. Prvo pozvano predavanje "Dosjetljivije metode: narativne tehnike u argumentaciji" održao je profesor Christopher Tindale, poznati svjetski retoričar i filozof $s$ windsorskog sveučilišta u Kanadi. Naslov i inspiraciju za svoje predavanje dobio je iz knjige filozofa Dennetta u kojoj autor tvrdi da je jedini način na koji se ljude može potaknuti da ozbiljno razmišljaju o idejama taj da se upotrijebi nešto drugo umjesto uporabe formalnog argumenta, a to je "pričanje priče" ili, kako ju autor naziva, "dosjetliivija metoda". Tindale istražuje kontrast između formalnog argumenta i priče kao moguću metodu uvjeravanja, promatra naraciju kao moguće sredstvo uvjeravanja te na koji način ona može uvjeriti publiku. Osim toga, smatra da je za naraciju vrlo bitna priroda 
i snaga kognitivnog okruženja unutar kojeg svaki čovjek djeluje u interakciji s ostalima. Profesor Michael Burke sa sveučilišta u Utrechtu, kao drugi pozvani predavač, održao je predavanje "Retorika sa stilom: može li razmatranje stilistike pomoći proučavanju retorike?". Osvrnuo se na važnost stilistike koja se razvila iz trećega govorničkog umijeća, točnije odabira pravog stila i gramatike te podsjetio kako je dublje poznavanje klasične retorike neophodno za pravilno tumačenje stilistike. Burke ističe kako je stilistika dio retorike te ju dijeli na gramatiku, pragmatiku, stil i ostale dijelove koje razrađuje u detalje. Stilistika nedvojbeno daje dubinu i širinu retoričkoj analizi, ali ono što Burke tvrdi jest da isto vrijedi i obrnuto, a to znači da retorička analiza daje dubinu i širinu stilistici. Treće plenarno predavanje održao je prof. dr. sc. Krešimir Bagić, vodeći hrvatski stručnjak za stilistiku s Filozofskog fakulteta u Zagrebu. U svom predavanju osvrnuo se na povijest anagramiranja od antike do danas te pokazao kako počeci anagrama sežu daleko u prošlost, točnije u 3. st. pr. n. e., kada su pjesnici u staroj Grčkoj koristili anagrame kako bi anagramirali imena vladara i kraljeva. Zanimljivo je bilo čuti da je jedan od najistaknutijih lingvista 20. stoljeća, Ferdinand de Saussure, izgleda veću pažnju posvetio proučavanju anagrama, nego svom najpoznatijem, postumno objavljenom djelu Tećaj opće lingivistike, o čemu svjedoče bilješke o mogućim anagramima kojima je ispunio 141 bilježnicu. Sudionici su, osim plenarnih predavanja, imali prigodu čuti i razna druga zanimljiva izlaganja. Prigodu za još bolje upoznavanje sudionici su dobili u četvrtak, u neformalnom ozračju, kada je organiziran izlet po otoku Braču. Predivno vrijeme, zajedno sa zanimljivim programom, koji je uključivao posjet galeriji u unutrašnjosti otoka, knjižnici u Supetru te isprobavanje lokalnih specijaliteta, pridonijelo je ugodnoj i prijateljskoj atmosferi konferencije. Posljednji dan konferencije donio je cjelodnevna izlaganja te zatvaranje konferencije. Nakon toga održana je svečana večera uz prigodni program na kojem su se sudionici neformalno družili, što je rezultiralo novim poznanstvima, razmjenama iskustava te pozivima na nove konferencije. Na svečanoj večeri najavljena je i sljedeća konferencija koja će se održati na istom mjestu za dvije godine. Vidimo se u Postirama! 